\title{
KUALITAS PERKAWINAN DAN DAMPAKNYA TERHADAP KESEHATAN MENTAL ANAK
}

\author{
Alfina E. Notti ${ }^{1 *}$, Delsylia Tresnawaty Ufi ${ }^{1}$ \\ ${ }^{1}$ Institut Agama Kristen Negeri Kupang, Kupang 85112, Indonesia \\ *) E-mail: delsyliaufi@staknkupang.ac.id
}

\begin{abstract}
Abstrak
Di dalam penelitian ini dilatarbelakangi oleh permasalahan mengenai kualitas perkawinan dan dampaknya terhadap kesehatan mental anak. Sistem perkawinan yang sehat, merupakan relasi yang baik antara suami dan istri serta hubungan orangtua dan anak-anak. Sedangkan perkawinan yang tidak sehat karena orang tua yang suka cekcok, dan karena masih menjalani hubungan dengan wanita idaman lain dan pria idaman lain, maka berdampak pada kesehatan mental anak. Tujuan penelitian ini adalah untuk mengetahui kualitas perkawinan dan dampak pada kesehatan mental anak berusia 6-12 tahun di desa Tesabela, Kecamatan Kupang Barat, Kabupaten Kupang. Metode yang digunakan dalam penelitian ini adalah metode penelitian kualitatif dengan subjek berjumlah 7 orang yang terdiri atas 2 keluarga. Berdasarkan hasil analisis data diperoleh dari masing-masing keluarga mengatakan bahwa dalam perkawinan yang sudah dibangun selama ini cenderung di dalam sikap maupun kata-kata sering menyertakan kekerasan secara verbal dan nonverbal yang dapat berdampak pada kesehatan mental anak, di mana anak merasa bodoh sehingga berkelanjutan dengan dampak anak lambat dalam hal berpikir dan yang belum terarah. Dampak kesehatan mental terhadap kelakuan anak yang nakal, sering menyendiri, dan berkemauan keras. Demikian juga dampak yang ditimbulkan adalah anak menjadi pendiam dan pemalu, tidak menghargai khususnya pada ayah dan bersifat kasar. Akibatnya anak memiliki perasaan tentang keadaan diri yang kurang diterima.
\end{abstract}

Kata kunci: anak, keluarga, kesehatan mental, kualitas perkawinan

\section{The Quality of Marriage and its Impact on the Mental Health of children}

\begin{abstract}
This research is motivated by problems regarding the quality of marriage and its impact on the mental health of children. A healthy marriage system is a good relationship between husband and wife as well as the relationship between parents and cildren. Meanwhile, unhealthy marriages because parents are bickering, and because they are still in relationships with other ideal women and other ideal men, have an impact on the mental health of the children. The purpose of this study was to determine which families in unhealthy marriages have an impact on the mental health of children aged $6-12$ years in Tesabela Village, West Kupang District, Kupang Regency. The method used in this study is a qualitative research method with 7 subjects consisting of 2 families. Based on the result of the data analysis obtained from each family, it is said that in marriages that have been built so far, the attitude and words often include non-verbal violence which can have an impact on the mental health of the child, where the child feels stupid so that it issustainable. With the impact of the child being slow in thinking and unfocused. Mental health impacts on child behaviour that is naughty, often aloof, and strong-willed. Likewise, the resulting impact is that the child becomes quiet and shy, does not respect especially the father and is rude. As a result, the child has feelings about their self that are less than acceptable.
\end{abstract}

Keyword: children, family, mental health, quality of marriage

\section{PENDAHULUAN}

Perkawinan merupakan bagian penting dalam proses perjalanan hidup manusia. Perkawinan adalah bersatunya seorang laki-laki dengan seorang wanita yang telah disahkan 
dan diberkati oleh Allah. Oleh karena itu, pernikahan bukanlah semacam kontrak perusahaan, atau bukan pula perjanjian timbal balik, di mana seorang laki-laki dan wanita saling memberi dan menerima (Parluhutan 2015). Melalui pernikahan yang dibina dalam suatu rumah tangga dapat membentuk adanya keluarga. Keluarga terbentuk dari adanya ikatan pernikahan antara suami istri yang hidup bersama-sama untuk mencapai hidup kekal dan abadi dengan rasa cinta, kasih, dan sayang berdasarkan KeTuhanan Yang Maha Esa. Dengan kata lain syarat terbentuknya keluarga adalah adanya pernikahan atau ikatan perkawinan (Marwisni, 2012).

Dalam keluarga juga terdapat di dalamnya ada setiap anggota keluarga yaitu: suami, istri dan anak-anak, sehingga keluarga itu akan berperan aktif untuk mencapai cita-cita kehidupan keluarga yang sejahtera secara jasmani dan rohani. Keluarga yang sehat secara jasmani dan rohani akan berdampak pada kesehatan mental anak dan masyarakat sekitarnya (Diana 2017). Menurut Geldard (2011) bahwa kenyamanan, keselamatan, kesejahteraan ekonomi, material, kesejahteraan psikologis, fisik, emosional, dan spiritual adalah kebutuhan dari seluruh anggota keluarga yang harus dipenuhi oleh keluarga. Selain itu, keluarga juga harus mampu memberikan kasih sayang, yang teruwujud melalui komunikasi yang dibangun dalam keluarga (ayah, ibu dan anak) (Willis, 2013). Dengan kata lain seluruh anggota keluarga baik itu anak-anak maupun orang tua dapat memiliki kesehatan mental yang baik, jika fungsi keluarga dapat berjalan sebagaimana mestinya. Manfaat jalannya fungsi keluarga secara optimal dapat berdampak tidak saja pada anggota keluarga, tapi juga berdampak pada kehidupan masyarakat di mana kesehatan mental yang baik jika dimiliki oleh masyarakat, maka akan membawa perubahan yang signifikan dan meningkatkan produktifitas lingkungan masyarakat itu sendiri (Sommer, Ness dan Borg, 2018).

Kehidupan keluarga yang sehat akan mampu menyesuaikan diri terhadap tuntutan zaman, namun sekaligus dapat bertahan terhadap berbagai pengaruh negatif yang datang dari masyarakat di luar kehidupan keluarga. Karena itu, sebagai orang tua perlu saling memahami untuk membangun kualitas perkawinan dan kehidupan keluarga yang harmonis (Seniawan, 2018). Keluarga yang harmonis menunjukkan kehidupan perkawinan yang sehat. Ciri perkawinan yang sehat menurut Simanjuntak (2012) dapat dilihat dalam kehidupan relasi dan emosi yang sehat dalam keluarga yakni yang memiliki waktu yang cukup untuk keluarga, melibatkan anggota keluarga, cuti ketika ada masalah, hidup yang transparan sebagai ketahanan mental seseorang. Sedangkan perkawinan yang tidak sehat disebabkan adanya perselingkuhan, terlalu banyak perbedaan, pengorbanan yang tidak seimbang, tidak ada komunikasi, dan kesamaan yang tidak sehat dalam mengatur finansial keluarga.

Selain itu kualitas perkawinan yang tidak sehat dilihat dari faktor kecanduan minuman keras dan penghianatan terhadap keluarga (Ernawaty, 2011). Oleh sebab itu, setiap keluarga harus berusaha dalam mencapai fungsi keluarga, antara lain a) fungsi biologis, dimana keluarga dipandang sebagai pranata sosial yang memberikan legalitas, kesempatan dan kemudahan bagi para anggotanya untuk memenuhi biologisnya, b) fungsi ekonomi dimana keluarga (dalam hal ini ayah) berkewajiban untuk menafkahi anggota keluarganya sesuai dengan kesanggupannya, c) fungsi pendidikan (edukatif) yaitu keluarga merupakan lingkungan pertama dan utama bagi anak, dimana keluarga bertugas memberikan keyakinan agama, nilai budaya, nilai moral dan keterampilan, d) fungsi sosialisasi, yaitu keluarga merupakan faktor penentu yang sangat mempengaruhi kualitas generasi yang akan datang (Yusuf, 2016). Dengan tercapainya fungsi keluarga, maka, dapat tercipta kualitas perkawinan yang sehat, yang merupakan wujud dari adanya relasi yang baik antara suami dan istri serta hubungan orang tua dan anak-anak.

Relasi orang tua dan anak-anak akan menjadi model dalam pembentukan keluarga bagi anak itu sendiri. Dalam keluarga pun anak akan melihat pola didikan orang tua dan menjadikannya sebagai contoh bagi kehidupannya kelak. Oleh karena itu, orang tua mesti menunjukkan hubungan keluarga yang sehat lewat kehidupan pernikahan yang sehat pula. 
Pernikahan yang sehat berfungsi untuk menghasilkan anak-anak yang sehat secara mental. Apabila keluarga tidak mampu untuk menerapkan fungsi-fungsi keluarga, maka keluarga akan menalami permasalahan yang akan berakibat pada rusaknya kekokohan keluarga yang berdampak pada kkerasan dalam rumah tangga juga berdampak pada perkembangan anak (Ifdil, 2018). Oleh karena itu, setiap orang yang menikah dan menjadi orang tua perlu menyadari konsekuensi ini, yaitu orang tua dipanggil untuk menjadi reflektor kasih Allah bagi anak-anak (Simanjuntak 2012). Anak akan melihat Tuhan melalui orang tuanya. Apabila orang tua benar, maka anak-anak mempunyai konsep yang benar tentang orangtuanya. Jika orangtua tidak benar maka anak-anak tidak mempunyai suatu konsep yang benar tentang bagaimana seharusnya menjadi manusia (Tong. S. 2014). Oleh sebab itu, keluarga merupakan salah satu sasaran dalam meningkatkan kesehatan mental (Sulistiowati, Prapti, Sawitri, Utami, Astuti dan Saputra (2015).

Kesehatan mental adalah pengetahuan dan perbuatan yang bertujuan untuk mengembangkan dan memanfaatkan potensi, bakat dan pembawaan yang ada semaksimal mungkin, sehingga membawa kebahagiaan diri dan orang lain, serta terhindar dari gangguan dan penyakit jiwa, dengan kata lain penyesuaian diri terhadap lingkungan sosial (Hamid, 2017). Sedangkan Winurini (2019) kesehatan mental adalah suatu kondisi ketika seseorang memiliki pandangan yang positif tentang kehidupannya, dapat menjalankan fungsi psikologis dan sosialnya dengan baik, mampu mengatasi masalah dalam dirinya, serta terhindar dari masalah-masalah gangguan mental. Selanjutnya menurut Undang-Undang No 3 Tahun 1966 yang dimaksud dengan kesehatan jiwa adalah keadaan jiwa yang sehat menurut ilmu kedokteran, sehingga memungkinkan perkembangan fisik, intelektual dan emosional yang optimal dari seseorang (Putri, Wibhawa, dan Gutama, 2014). WHO memberi penjelasan bahwa kesehatan mental merupakan kondisi dari kesejahteraan yang disadari individu, yang didalamnya terdapat kemampuan-kemampuan untuk mengelola stress kehidupan wajar, untuk bekerja secara produktif dan menghasilkan serta berperan dalam komunitasnya. Berdasarkan beberapa pengertian kesehatan mental ini, maka dapatlah dipahami bahwa kesehatan mental merupakan hal yang sangat penting bagi hidup seseorang yang akan mengakibatkan orang tersebut dapat bekerja secara maksimal di lingkungan dimana ia berada. Oleh karena itu, kondisi mental yang sehat tidak dapat terlepas dari kondisi kesehatan fisik yang baik. Dengan memiliki kesehatan mental yang baik, maka individu terbebas dari segala jenis gangguan jiwa, dan mampu untuk menyesuaikan diri dengan dirinya sendiri, dengan orang lian dan masyarakat serta lingkungan di mana ia hidup, termasuk dalam menghadapi masalah-masalah di sepanjang hidupnya (Putri, Wibhawa, dan Gutama, 2014).

Individu yang dapat menyesuaikan diri dengan keadaan hidupnya menunjukkan bahwa dirinya memiliki mental yang sehat. Ciri-ciri seseorang yang "sehat jiwa atau mental" adalah merasa senang terhadap dirinya yakni mampu menghadapi situasi, mampu mengatasi kekecewaan dalam hidup, puas dengan kehidupannya sehari-hari, mempunyai harga diri yang wajar, menilai dirinya secara realistis, tidak berlebihan dan tidak pula merendahkan; selanjutnya individu yang sehat mental akan merasa nyaman berhubungan dengan orang lain, yakni mampu mencintai orang lain, mempunyai hubungan pribadi yang tetap, dapat menghargai pendapat orang lain yang berbeda, merasa bagian dari suatu kelompok, tidak "mengakali" orang lain dan juga tidak membiarkan orang lain "mengakali" dirinya; selain itu sehat mental dari individu yakni mampu memenuhi tuntutan hidup, diantaranya menetapkan tujuan hidup yang realistis, mampu mengambil keputusan, mampu menerima tanggungjawab, mampu merancang masa depan, dapat menerima ide dan pengalaman baru serta puas dengan pekerjaannya. Selain itu, kriteria sehat mental menurut Tirtawati, (2016) yakni bertanggungjawab yaitu berani menghadapi segala hal yang dilakukan; dewasa yaitu memiliki skap dan perilaku yang tidak kekanak-kanakkan; menghormati, dan menghargai orang lian yaitu berperilaku sopan santun sesuai aturan, nilai, norma dan adat-istiadat yang ada disuatu tempat; optimis, yaitu berpikir dalam menghadapi kehidupan; beriman dan 
bertaqwa yaitu percaya kepada Tuhan Yang Maha Esa dan melaksanakan perintahNya serta meninggalkan laranganNya; serta disiplin, yaitu taat dan patuh pada aturan yang ada.

Simanjuntak (2012) menjabarkan tujuh dimensi kasih Allah yang harus direfleksikan setiap orang tua, yakni sikap kepedulian, tanggung jawab, disiplin, murah hati, respek, pengenalan, dan pengampunan. Namun dalam realitas, tidaklah mudah dalam membangun sistem pernikahan yang sehat, akibatnya banyak keluarga yang berada diujung tanduk, dan berujung pada perceraian, stres berkepanjangan, atau depresi, narkoba dan sebagainya. Keadaan seperti ini akan berpengaruh pada kehidupan anak. Anak sebagai seorang individu dikatakan sehat secara mental adalah individu yang flourishing, yakni Individu yang bisa merasakan emosi positif tentang kehidupannya serta dapat berfungsi secara psikologis maupun secara sosial. Sedangkan individu yang tidak sehat mentalnya disebut individu languishing, yakni individu yang tidak memiliki emosi positif, dan tidak berfungsi dengan baik secara psikologis maupun sosial (Winurini, 2019).

Dengan demikian kualitas yang baik bagi anak-anak, adalah dengan memperhatikan kesehatan mental anak. Kesehatan mental karenanya tidak bisa dilepaskan dari sistem pernikahan yang sehat. Pernikahan yang sehat didapati dari kualitas pernikahan yang baik. Sebagaimana penelitian dari Puspitawati, Aiziza, Mulyana, dan Rahma (2019) bahwa kualitas pernikahan merupakan derajat yang dapat memberi kebahagiaan dan kesejahteraan bagi pasangan suami istri sehingga dapat menjaga kelestarian pernikahan. Kualitas pernikahan diperoleh dari keharmonisan komunikasi suami dan istri sehingga tercapai suasana nyaman untuk mengoptimalkan pengasuhan yang diberikan kepada anak (Nurani dalam Tyas, F.P.S., dan Herawati 2017). Kelestarian pernikahan berdampak pada pernikahan yang sehat pula. Sebab, dalam diri anak-anak yang mudah stres, mengalami depresi hingga kecanduan narkoba ternyata ditemukan berakar pada masalah dengan keluarga yang tidak sehat dan tidak berfungsi dengan baik (Simanjuntak 2012). Menurut Santrock (2012) terdapat faktor-faktor sebagai pemicu timbulnya masalah mental emosional pada anak, yaitu dari lingkungan keluarga, lingkungan teman sebaya, lingkungan sekolah, masyarakat dan sosial. Lingkungan keluarga adalah terkait pola asuh orang tua, keharmonisan keluarga, kedekatan saudara kandung, hal sosial ekonomi keluarga dan pendidikan moral. Oleh sebab itu, pentingnya komunikasi yang diterapkan oleh orang tua dalam keluarga, karena orang tua menjadi basis nilai bagi anak. Menurut Yuli (2020) bahwa nilai-nilai yang ditanamkan orang tua akan lebih banyak dicerna dan dianut oleh anak sehingga lambat laun ikut membentuk kepribadian anak. Selain komunikasi yang perlu bagi orang tua dan anak, maka penting adanya sikap saling terbuka dalam keluarga, agar orang tua dan anak dapat saling mendengarkan.

Anak yang sehat secara mental membutuhkan waktu yang cukup dari orang tua yang mampu mengatur keseimbangan antara karier dan pekerjaan. Anak-anak juga mendapat perioritas dalam semua aktifitas orang tua, karena anak menjadi pusat pertumbuhan. Seiring dengan proses pertumbuhan dan perkembangan anak, dari bayi hingga dewasa, maka lingkungan keluarga memegang peran penting dalam mencapai jiwa yang sehat. Pencapaian jiwa atau mental yang sehat dperlukan usaha dan waktu (Putri, Wibhawa, dan Gutama, 2020). Di samping itu, anak juga akan memiliki kesehatan mental karena dibesarkan oleh orang tua dengan penuh kasih sayang, diasuh dengan disiplin dan yang berdampak pada kecerdasan emosi anak, sehingga anak mampu mengelola emosi diri sendiri. Sebab, dalam keluarga, seseorang pertama kali mengalami kesenangan, kesedihan, kekecewaan, kasih sayang bahkan mungkin celaan, karena hidup berkeluarga dipengaruhi oleh kehidupan perasaan dan suasana emosi (S. 2012). Sebagaimana yang diungkapkan oleh Dewi (Dewi 2012) bahwa individu yang sehat mental adalah yang memiliki kemampuan untuk menahan diri, menunjukkan kecerdasan,berperilaku dengan menenggang perasaan orang lain, serta memiliki sikap hidup yang bahagia. Selanjutnya, anak akan bertumbuh secara seimbang baik fisik, emosi, sosial dan spiritual. Hal tersebut menjadi bekal bagi anak untuk berhasil dalam studi, karier dan perkawinan mereka kelak (Simanjuntak 2012). 
Keberhasilan hidup anak menunjukkan adanya keseimbangan relasi dengan orang tua. Walaupun tidak dapat dipungkiri bahwa ada kecendrungan terjadi pertengkaran tetapi dapat kembali ke keadaan damai, dan sebaliknya. Dengan demikian masing-masing anggota keluarga berusaha memelihara keseimbangan dalam sistem keluarga, sebab baik sadar atau tidak, relasi suami istri turut mempengaruhi karakter keseimbangan keluarga (Simanjuntak 2012). Menurut Djayadin dan Munastiwi (2020) keluarga merupakan lingkungan pertama yang dikenal anak, dan berperan penting bagi perkembangan mental anak. Selain itu, dengan mendapatkan didikan dari orang tua maka akan berdampak pada psikologi anak, yaitu pemikiran dan mental yang sehat, pengukuhan egoisme, harga diri, kepekaan terhadap mengadaptasikan diri dengan lingkungan. Sebaliknya, perkembangan psikologi anak yang kurang baik diamati lewat rendahnya harga diri dan timbul masalah tingkah laku dan mental, anak tumbuh tidak sehat, ia ditolak oleh lingkungannya, suka berprasangka bahwa kebaikkan yang diberikan orang lain menyimpan maksud tertentu. Sebab, perkembangan psikologis yang positif penting untuk perkembangan psikologi anak. Dengan demikian orang tua perlu memahami anak sesuai tahap perkembangannya agar anak menjadi lebih optimal. Disitulah orang tua harus menunjukkan wibawa yang benar dihadapan anak supaya anak tidak mengalami stress (Tong. S. 2014).

Stres adalah gangguan atau kekacauan mental dan emosional yang bisa terjadi pada siapapun termasuk pada anak-anak. Menurut Djayadin dan Munastiwi, (2020) tanda-tanda yang menunjukkan anak stress atau kesehatan mentalnya terganggu adalah secara umum perubahan dalam bentuk internalize problem di mana anak akan lebih menarik diri, lebih cemas, tidak ceria, kurang selera makan, dan sebagainya. Sedangkan externalize problem di mana anak terlihat seperti lebih agresif, mudah kesal, sulit kooperatif, melakukan kekerasan pada orang lain atau benda. Dengan kata lain, emosi anak yang merupkan mental ini dalam perkembangan tergantung dengan proses belajar dengan lingkungan. Dalam proses belajar tersebut, anak akanmenyerap setiap perilaku, penilaian dan perlakuan, orang-orang yang ada disekitarnya dan keluarga menjadi faktor penentu perkembangan emosi anak. Di usia ini bimbingan orang tua menjadi hal yang mutlak mengingat emosi anak yang labil dan efek lanjutan yang mungkin timbul akibat gangguan tersebut (Sumantri 2014). Jika anak masih kecil berada di dalam keluarga yang tidak bertanggungjawab anak selalu dibingungkan oleh orang tua yang senantiasa tidak harmonis maka anak akan merasa tidak aman dan kurang merasa diterima oleh keluarganya. Anak-anak seperti itu merasa kurang disayangi. Sebaliknya jika anak merasa disayangi akan menunjukkan kehidupan mental yang sehat. Adapun ciri kesehatan mental menurut Wiramihardja (Wiramihardja 2015) adalah memiliki kematangan emosional, mampu melihat realitas, kemampuan untuk hidup bersama dan bekerja sama, memiliki filsafat hidup. Sedangkan Simanjuntak (Simanjuntak 2012) mengatakan kesehatan mental seseorang dapat dilihat dari memiliki sikap positif terhadap diri sendiri, mampu mengaktualisasi dirinya dengan baik, seseorang yang berintegritas, memiliki otonomi pribadi, memiliki persepsi yang akurat terhadap realitas, dan penguasaan terhadap situasi. Sebaliknya individu yang tidak memiliki kesehatan mental adalah individu yang tidak mampu menyesuaikan diri yang dapat dilihat dari perkawinan orang tua yang tidak sehat.

Jika dilihat pada kenyataannya, yakni yang terdapat di Desa Tesabela, Kecamatan Kupang Barat, Kabupaten Kupang, kurang lebih ada dua keluarga yang masih menjalani kehidupan perkawinannya yang bermasalah, dari hasil observasi dan wawancara pada keluarga yang pertama berinisial N.W umur 51 tahun, bekerja sebagai PNS di sebuah kantor dinas bersama pasangannya R.W umur 47 tahun, sebagai ibu rumah tangga memiliki anak 4 orang, mengakui bahwa kenyataannya dari hubungan suami istri sering terjadi percecokan. Di mana subjek R.W mengakui ia merasa emosi meningkat kalau N.W selalu pulang kantor tidak tepat waktu selalu pulang malam hari dalam keadaan mabuk karena minum minuman keras, lalu tidak mengindahkan R.W yang sedang menunggu di rumah dengan resah dan gelisah. Sedangkan subjek N.W merasa santai saja dengan perilakunya. Subjek N.W juga terlibat dalam hal keinginan yaitu selalu menunjukan perilaku yang kurang pantas, 
contohnya: mencium atau mencolek anak gadis yang subjek N.W merasa sudah dekat, hal ini membuat subjek R.W merasa malu dan sakit hati dengan keadaan yang dialaminya. Sehingga keadaan ini berpengaruh pada pertumbuhan anak bungsunya yaitu S.W yang berumur 10 tahun, yang selalu mengalami ketakutan dan kurang percaya diri kalau melihat orangtuanya bertengkar yang hebat.

Demikian juga pada pasangan J.B umur 45 tahun dan E.B umur 40 tahun, mereka memiliki 1 orang anak, pasangan ini bekerja sebagai petani. Berdasarkan observasi dan wawancara peneliti menemukan bahwa subjek menunjukan perilaku mengenai kehidupan perkawinan yang tidak sehat. Dalam kasus ini mengenai perilaku pasangan yang terjadi adalah pasangan suami-istri sebelumnya menjalin hubungan tanpa status (belum resmi dinikahkan secara gereja dan adat), tetapi pasangan suami istri tetap hidup serumah. Tetapi, setelah dinikahkan secara sah oleh adat, gereja dan pemerintah, pasangan ini menjalin hubungan lagi bersama orang-orang terdekat dalam hal ini sekampung atau dalam keluarga (memiliki wanita idaman lain dan pria idaman lain), dan anehnya pasangan suami istri tersebut mengatakan bahwa selalu merasa nyaman dengan keadaan ini. Dalam kesaksian pasangan suami istri selalu mengatakan bahwa untuk anak, pasangan ini bisa mendidik anak dengan baik. Berdasarkan gambaran perilaku di atas, bahwa jika ingin kualitas dan masa depan yang baik bagi anak-anak, maka kita harus memperhatikan kesehatan mental anak-anak. Oleh karena itu kesehatan mental yang baik didapati dari sistem pernikahan yang sehat (Simanjuntak 2012).

Kebanyakan orang tua sungguh-sungguh mau membesarkan anak-anak mereka dengan baik. Mereka tidak berniat mengabaikan atau mencelakakan anak-anak mereka. Namun kenyataannya banyak orang tua yang begitu sibuk dengan rutinitas sehari-hari sehingga peran pengasuhan mereka bergeser menjadi hal sekunder. Sedihnya mereka sering sekali sunguh-sungguh memberi perhatian kepada anak-anak mereka hanya ketika masalah muncul. Oleh karena itu, penting adanya kesehatan mental keluarga yang dilihat dari sistem keorangtuaan yang sehat, teladan ayah, cinta dalam pertumbuhan anak (perasaan terhubung dengan orang tua, butuh diterima, dan dipedulikan), bila disayang mudah berkembang, cinta yang dibutuhkan anak lewat pemberian pujian dan afirmasi, sentuhan fisik, waktu yang berkualitas, melayani anak, dan pemberian (gift) (Simanjuntak, 2012). Dengan demikian, keluarga yang sehat sesungguhnya dapat berdampak pada kesehatan mental terkait perasaan, pikiran dan kelakuan anak (Simanjuntak, 2012). Berdasarkan latar belakang dan masalah tersebut, penelitian yang berjudul "Kualitas Perkawinan dan Dampaknya terhadap Kesehatan Mental Anak" dilakukan.

\section{METODE}

Metode penelitian yang digunakan adalah metode penelitian kualitatif. Penelitian dilakukan di Desa Tesabela, Kecamatan Kupang Barat, Kabupaten Kupang. Subjek yang akan penulis pilih dalam penelitian ini adalah 2 keluarga yakni 2 pasangan suami istri dan 4 orang anak usia 6-12 tahun. Teknik pengumpilan data dilakukan dengan teknik observasi, dan wawancara. Dalam observasi ini, peneliti terlibat dengan kegiatan sehari-hari orang yang sedang diamati atau yang digunakan sebagai sumber data penelitian. Sambil melakukan pengamatan, peneliti ikut melakukan apa yang dikerjakan oleh sumber data, dan ikut merasakan suka dukanya. Dengan observasi partisipan ini, maka data yang diperoleh akan lebih lengkap, tajam, dan sampai mengetahui pada tingkat makna dari setiap perilaku yang nampak (Sugiyono, 2014). Wawancara yang digunakan adalah wawancara mendalam (indepth interview) terhadap subjek atau informan yang kemudian hasil wawancara dibandingkan dengan teori dan kepustakaan yang ada. Pedoman wawancara yakni terkait kualitas perkawinan, kesehatan mental keluarga dan kualitas perkawinan serta dampaknya terhadap kesehatan mental anak. Analisis data kualitatif dilakukan dengan reduksi data yakni analisis data yang dilakukan dengan memilih hal-hal yang pokok, memfokuskan pada hal-hal 
yang penting, lalu di cari tema dan polanya. Penyajian data yang bersifat naratif bila tidak ditemukan bukti-bukti atau uraian singkat, bagan, hubungan antar kategori dan sejenisnya dan kesimpulan, yakni dari data yang diperoleh lalu dikategorikan, di cari tema dan polanya, kemudian ditarik kesimpulan. Kesimpulan awal yang dikemukakan masih bersifat sementara dan akan berubah bila tidak ditemukan bukti-bukti yang kuat dalam tahap penumpulan data berikutnya (Moleong, 2013).

\section{HASIL DAN PEMBAHASAN}

\section{A. Kualitas Perkawinan}

Kualitas perkawinan dapat dilihat dari perkawinan yang tidak sehat. Perkawinan yang tidak sehat dapat diketahui melalui dua faktor (Ernawaty, 2011) yakni kecanduan minuman keras, dan penghianatan terhadap keluarga. Hasil penelitian dan pembahasan kedua faktor tersebut sebagai berikut:

\section{Kecanduan Minuman Keras}

Ditemukan pada hasil penelitian bahwa suami dari subjek pada kedua pasangan sering menghabiskan waktu dengan minum-minuman keras dan mengabaikan keluarga. Pulang rumah dengan keadaan mabuk menyebabkan seringkali terjadi pertengkaranpertengkaran diantara pasangan keluarga tersebut. Bahkan dengan keseringan mabuk akibat minuman keras menyebabkan ketidakpedulian terhadap keluarga yakni kepada isteri dan anak. Isteri merasa diabaikan sedangkan anak merasa kurang adanya perhatian dari sang ayah.

Berdasarkan hasil penelitian tersebut di atas, menunjukkan bahwa kualitas perkawinan diperoleh dari adanya kepedulian, dan perhatian. Sebaliknya tidak adanya kepedulian dan perhatan karena minuman keras dan mabuk meruntuhkan kualitas perkawinan tersebut. Perkawinan yang berkualitas menurut Setiawati dan Nurhayati (2020) didapat dari rasa saling memberi, mendukung, bekerjasama, perhatian, dan kasih sayang diantara anggota keluarga. Adanya rasa saling memberi ini turut menciptakan keluarga yang berkualitas. Adanya perasaan mendukung dan perhatian juga dapat mewujudkan relasi kehidupan suami istri yang harmonis. Tingginya kualitas relasi suamiistri terkait perilaku yang berhubungan dengan dukungan, kedekatan, komunikasi, kehangatan dan penerimaan antara suami dan istri (Setiawati dan Nurhayati, 2020).

\section{Penghianatan Terhadap Keluarga}

Hasil penelitian menunjukkan bahwa pasangan dari subjek R.W dan E.B melakukan hubungan dengan wanita lain yang juga sekampung dengan mereka, bahkan R.W terbiasa mencium dan mencolek anak gadis yang sekampung dengan mereka. Perilaku ini oleh subjek R.W merasa tidak pantas dan menyakiti hati juga menyakiti hati anak-anak. Sedangkan justru perselingkuhan yang dilakukan oleh suami dari subjek E.B dianggap biasa, sebab oleh E.B sendiri juga melakukan hal tersebut.

Berdasarkan hasil penelitian di atas diketahui bahwa adanya kualitas perkawinan yang terganggu karena terdapat penghianatan terhadap keluarga. Tanda perkawinan yang tidak sehat dan tidak berkualitas adalah salah satu pasangan sudah mulai berselingkuh (Gunarsa, 2012). Keadaan ini memicu terjadinya perkawinan yang tidak berkualitas. Perkawinan yang tidak berkualitas menyebabkan gangguan psikologis, menurunkan produktivitas, terjadinya konflik interpersonal, bahkan perceraian sehingga menyebabkan ketidakbahagiaan dalam keluarga (Rahma, Rahman dan Fitriah, 2017). Sebaliknya perkawinan yang berkualitas memberi dampak pada kesehatan mental dan kesejahteraan, sebab perkawinan mengakibatkan kedua pasangan suami istri akan merasa lebih sehat dan puas dengan hidup mereka (Fu dan Noguchi, 2016). 
Notty \& Ufi, JKKP 8 (01) (2021) 108-119

\section{B. Kesehatan Mental Keluarga}

Kesehatan mental keluarga dapat dilihat pada aspek-aspek seperti sistem keorangtuaan yang sehat, teladan ayah, perasaan diterima, pujian dan afirmasi (Simanjuntak, 2012).

\section{Sistem Keorangtuaan}

Berdasarkan hasil penelitian menunjukan bahwa sistem keorangtuaan dapat diamati dari bagaimana pemahaman keluarga tentang nilai-nilai spiritual. Kenyataannya, keluarga sebagai subjek pertama dan subjek kedua mengabaikan penanaman nilai-nilai spiritual kepada anggota keluarga. Subjek pada kedua pasangan suami isteri mengatakan mereka kurang menjadikan Firman Tuhan sebagai pusat iman tetapi gereja sebagai pusat iman dengan menyuruh anak-anak rajin ke sekolah minggu di gereja.

Penanaman nilai-nilai spiritual oleh orang tua pada anak penting dilakukan lewat komunikasi. Komunikasi orang tua kepada anak hanya dapat dibangun, jika orang tua juga memiliki komunikasi dengan Allah sebagai sumber iman. Sebagaimana (Simanjuntak 2012)mengatakan bahwa pasangan suami istri sebagai orang tua tunduk pada otoritas Allah untuk membangun komunikasi yang bersifat trialog, artinya, Allah dilibatkan dalam setiap proses pengambilan keputusan termasuk keputusan untuk mendidik anak dalam menanamkan nilai-nilai spiritual dalam hidupnya. Orang tua karenanya memegang peran penting dalan menanamkan nilai-nilai spiritual kepada anak dalam keluarga.

2. Teladan ayah

Bertolak dari hasil penitian terhadap kerinduan anak akrab dengan ayah untuk melihat teladan ayah, namun faktanya dalam kebanyakan peristiwa dalam hidup anak pada kedua subjek pasangan suami istri N.W dan R.W menemukan bahwa anak ingin ada sentuhan fisik dari ayah, tetapi ayah tidak peka denga bahasa non verbal. Ibunya ada di sana melakukan tugasnya, mengurus anak-anak, berbicara dengan anak-anak, dan meluangkan waktu dengan mereka akibatnya anak-anak tahu bahwa ibunya dapat terjangkau, mengasihi, komunikatif, dan menerima, tetapi dengan ayah berbeda. Sedangkan anak pada kedua subjek pasangan J.B da E.B keakraban ayah dan anak tergantung pada pemberian seperti makanan ringan oleh sang ayah.

Berdasarkan hasil penelitian tersebut, ayah kurang terlibat atau kurang komunikatif dengan anak-anaknya, Anak-anak merindukan apa yang tidak dimilikinya. Anak-anak yang rindu punya hubungan yang dekat dengan ayah mereka, sebab seorang anak rindu akrab dengan ayahnya. Jika kebutuhan anak akrab dengan ayahnya terpenuhi,maka akan membantu anak dalam masa-masa perkembangannya. Sebagaimana yang dikatakan oleh Cabrera (2000) bahwa pengalaman anak dengan ayahnya memberi kontribusi bagi perkembangan anak untuk merasakan kesejahteraan. Peran ayah terhadap anak juga diungkapkan oleh Hidayati, F., Kaloeti, D, V, S. (2011) bahwa hubungan emosional anak dengan ayah berpengaruh pada perkembangan kognitif, dan kompetensi sosial anak sejak dini.

\section{Perasaan Di Terima}

Menurut hasil penelitian terhadap perasaan diterima sebagai anak, diperoleh bahwa anak pada subjek N.W dan R.W merasa tidak diterima karena ketidakmampuannya dalam belajar di sekolah, sehingga anak subjek kedua pasangan sering dikatakan bodoh.sedangkan anak dari subjek pasangan R.B dan E.B sering dibanding-bandingkan dengan temanya yang lain dengan mengatakan anaknya tidak naik kelas karena nakal. Bahkan juga membandingkan dengan kakaknya yang memiliki kemampuan belajar yang lebih baik.

Berdasarkan hasil penelitian, maka perasaan diterima dapat dipahami anak melalui perkataan atau bahasa nonverbal yang memberi pengaruh pada psikis anak saat masa 
pertumbuhan dan perkembangannya. Sedangkan jika anak dibanding-bandingkan dengan saudara-saudarinya, maka anak akan merasa ada penolakan oleh karena keterbatasan yang dimilikinya. Menurut Simanjuntak (2012) bahwa, pertumbuhan anak terpengaruh dari perkawinan orang tua yang tidak sehat contohnya: kalau mereka mendengar perkataan dari orang tua mereka "dasar anak bodoh" atau "dasar anak malas, anak seperti ini nanti masa depannya tidak akan baik", maksudnya pada saat anak-anak percaya bahwa mereka bodoh, malas atau tidak patut dikasihi, mereka akan menjadi serupa dengan gambaran seperti itu. Dengan kata lain, anak menjadi belum mampu merasakan perasaan diterima jika menerima kritikan dari lingkungan keluarga terkhususnya orang tua. Putri, dan Najahi (2013) penerimaan diri seseorang salah satunya terkait bagaimana ia mampu menerima kritikan. Anak yang mempunyai pergumulan emosi yang lebih banyak di dalam kehidupannya, perlu mendapatkan belas kasihan bahkan lebih dimengerti, dan mendapat kasih sayang serta menerima mereka sebagaimana adanya (Mary dan Tong 2013).

\section{Pujian dan Afirmasi}

Hasil penelitian ditemukan bahwa pujian diberikan kepada anak ketika anak menuruti untuk melakukan apa yang diperintahkan oleh orangtua. Juga dengan cara ketika anak diminta pergi berbelanja ke kios untuk keperluan orangtua dengan mengucapkan kata terima kasih. Sedangkan jika anak berbuat salah maka anak dipukul.

Berdasarkan hasil penelitian di atas, maka jelas anak membutuhkan waktu yang berkualitas bersamanya karena itu sesibuk-sibuknya orang tua bekerja harus memiliki waktu luang berinteraksi bersama anak, jika tidak anak akan merasa kesepian, dan hal pemberian atau hadiah sebagai wujud cinta yang dapat dilihat dan dirasakan anak. Menurut Rohma (2018) bahwa anak yang diberikan penghargaan dalam wujud pujian terhadap usaha-usaha anak dan pencapaian yang dilakukan oleh anak, maka akan memicu semangat anak memiliki kepercayaan diri. Sedangkan menurut Wijayanto (2020) pemberian hadiah/reward diberikan oleh orangtua kepada anak membuat anak dapat mengembangkan diri dengan memiliki semangat berperilaku yang baik.

\section{Kualitas Perkawinan dan Dampak Kesehatan Mental Anak}

Dampak kesehatan mental dijelaskan oleh Dewi (2012), yakni dampak kesehatan mental terhadap pikiran, perasaan dan kelakuan. Terkait dampak kesehatan mental terhadap pikiran hasil penelitian menunjukkan anak dari masing-masing subjek pasangan suami istri merasa tidak cerdas, dan lemah karena sering dikatai bodoh oleh orangtua ketika tidak dapat mengerjakan tugas bahkan akibatnya sampai tidak naik kelas. Sedangkan dampak kesehatan mental terhadap perasaan adalah anak mengalami ketakutan jika berbuat hal yang salah. Sebab jika anak berbuat salah, maka anak akan menerima pukulan dari orangtua. Namun, anak- anak dari masing-masing subjek pasangan suami istri dapat merasakan ketentraman kalau orangtua merasakan kekhawatiran yang mendalam baik terpenuhinya kebutuhan anak dan juga pendampingan orang tua terhadap anak. Sedangkan kesehatan mental terkait kelakuan terkhususnya perasaan takut yang anak rasakan akibat dari perbuatan nakal, maka akan selalu mendapat pukulan dari orangtua, saat kehilangan kasih sayang, maka anak akan merasa emosi yang mendalam. Terdapat pengakuan dari anak masing-masing subjek pasangan suami istri bahwa akibat sering dipukul oleh orangtua, maka mereka juga sering melakukan kekerasan fisik (pukulan) dengan teman-temannya. Sehingga berkelanjutan dengan dampak anak lambat dalam hal berpikir dan berbicara belum terarah, nakal, sering menyendiri, dan berkemauan keras. Anak juga menjadi pendiam dan pemalu, tidak menghargai khususnya pada ayah dan bersikap kasar.

Hasil penelitian ini berkaitan dengan pendapat Gunarsa (2012) bahwa anak sehat secara mental jika anak memperoleh perlakuan yang baik di dalam keluarga yang sehat 
yang ditunjukkan melalui perilaku hidup yang baik. Perilaku orangtua juga berdampak pada kesehatan mental anak, di mana sebagai orangtua perbuatan yang ditunjukkan lewat kekerasan fisik (pukulan) pada anak berpengaruh pada masa pertumbuhan anak, yakni anak akan menjadi agresif dan anak sewaktu-waktu melakukan kekerasan fisik (pukulan) kepada orang tua. Anak mengalami situasi yang tidak menyenangkan dan tidak bisa berbuat apaapa lagi ketika ia menghadapi ancaman-ancaman, sehingga berdampak pada anak akan merasa bodoh dan berakibat pada anak lambat dalam hal berpikir dan berbicara, belum terarah, nakal, sering menyendiri, dan berkemauan kemauan keras. Anak juga kan menjadi pendiam dan pemalu, tidak menghargai khususnya pada ayah dan bersikap kasar. Oleh karena itu, peran orangtua baik dalam komunikasi atau model menjadi penting bagi anakanak, karena keluarga dengan kualitas perkawinan yang baik dapat dikatakan sebagai suatu badan sosial yang berfungsi mengarahkan kehidupan afektif seseorang. Oleh Karena itu, sebagai orang tua harus menunjukkan kewibawaan di depan anak dengan berperilaku baik, tidak melakukan kekerasan fisik. Demikian seperti yang dikatakan oleh Tong (2014) bahwa, orang tua sebagai wakil Tuhan harus menjadi contoh yang baik bagi anak.

Perilaku negatif orangtua dapat menyebabkan trauma pada anak-anak, yang dikenal dengan istilah trauma psikis, yaitu untuk menerangkan setiap pengalaman yang tidak menyenangkan, yang memberikan pengaruh pada terjadinya pemahaman negatif yang serius yang kemudian dapat menimbulkan cedera psikologis, sehingga anak mengalami situasi yang tidak menyenangkan, seperti menangis yang berkepanjangan hanya untuk mewujudkan keinginannya. Dengan demikian, orangtua perlu memelihara keseimbangan dalam keluarga, menjaga kualitas perkawinan untuk dapat memberikan rasa cinta dan menyayangi anak sehingga anak merasa terpelihara dan memiliki kesehatan mental.

\section{SIMPULAN DAN SARAN}

Perkawinan yang tidak sehat menunjukkan kualitas perkawinan itu sendiri melalui kecanduan mimum-minuman keras dan penghianatan terhadap keluarga. Sedangkan, kesehatan mental keluarga diperoleh dari sistem keorangtuaan yang dipahami dari menanamkan nilai-nilai spiritual dalam keluarga, anak perlu merasa dekat dengan ayah, anak penting untuk merasa diterima, dan dipahami melalui bahasa nonverbal. Anak juga membutuhkan pujian dan afirmasi, sentuhan fisik bukan pukulan, adanya waktu luang untuk berinteraksi bersama anak sehingga anak tidak merasa kesepian, dan anak merasa dilayani dengan kasih sayang. Anak juga membutuhkan adanya pemberian (gift) dari orang tua sebagai wujud cinta yang dirasakan anak. Perkawinan yang tidak sehat berdampak pada kesehatan mental anak, dampaknya yaitu pikiran, perasaan dan kelakuan. Dimana anak berpikir ia tidak cerdas atau bodoh. Dampak kesehatan mental pada perasaan, yakni ada ketentraman hati dirasakan anak ketika orangtua mengkhawatirkan anak. Namun, kesehatan mental anak berdampak pada kelakuan yakni anak juga sukamemukul teman-temannya, hal ini disebabkan karena anak merasa takut sering mendapat kekerasan fisik (pukulan) dari orangtua. Dengan demikian, perilaku negative orangtua dapat menyebabkan trauma pada anak-anak. Oleh Karena itu, orangtua perlu memelihara keseimbangan dalam keluarga, menjaga kualitas perkawinan dengan cara tidak menjadi pecandu minuman keras dan tidak menghinati perkawinan dengan adanya pihak ketiga dalam rumah tangga untuk dapat memberikan rasa cinta dan menyayangi anak sehingga anak merasa terpelihara dan memiliki kesehatan mental.

\section{DAFTAR PUSTAKA}

Cabrera, N., Tamis L, C., Bradley, R., Hofferth, S. \& Lamb, M. (2000). Fatherhood in the 21st Century. Child Development, 71, 127-136.

Dewi, K.S. (2012). Kesehatan Mental. Semarang: Lembaga Pengembangan Dan 
Penjaminan Mutu Pendidikan, Universitas Diponegoro.

Diana, L. T. Y. (2017). Kawin, Siapa Takut!. Jakarta: PT BPK Gunung Mulia.

Djayadin, C., dan Munastiwi, E. (2020). Pola Komunikasi Keluarga Terhadap Kesehatan Mental Anak di Tengah Pandemi Covid-19. Jurnal Raudhatul Athfal: Jurnal Pendidikan Islam Anak Usia DIni, vol 4(2) , 160-180

Ernawati, R. (2011). Mengatasi Kesehatan Mental Melalui Layanan Konseling Keluarga. Seminar International Conference On Guidance \& Counseling Bandung, 7-8 Desember 2011

Fu R., \& Noguchi, H. (2016). Does marriage make us healthier? Inter-country comparative evidence from China, Japan, and Korea. PLOS ONE, 11(2), e0148990. doi:10.1371/journal.pone.0148990

Geldard, K., And David Geldard. (2011). Konseling Keluarga. Yogyakarta: Pustaka Pelajar.

Gunarsa Y.S. (2012). Asas-Asas Psikologi Keluarga Idaman. Jakarta: PT. BPK. Gunung Mulia.

Hamid, A. (2017). Agama dan Kesehatan Mental Dalam Perspektif Psikologi Agama, Kesehatan Tadulako, Vol 3 (1), 3

Hidayati, F., Kaloeti, D, V, S., dan Karyono. (2011). "Peran Ayah Dalam Pengasuhan Anak." Jurnal Undip Vol.9., No.1, 1-10

Ifdil. (2018). Mengembangkan Kesehatan Mental di Lingkungan Keluarga dan Sekolah. Journal of Innovative Counseling: Theory, Practice \& Research, 2 (2): pp. 1-9

Marwisni, H. (2012). Bahan Ajar Bimbingan dan Konseling. In. Padang: Bk Fip Unp.

Moleong, L.J. (2013). Metodologi Penelitian Kualitatif. Bandung: PT. Remaja Rosdakarya Offset

Parluhutan, M. (2015). Pernikahan. Yogyakarta: ANDI.

Puspitawati, H., Aziza, Y., Mulyana, A., dan Rahma, A.F. (2019). "Ketahanan Keluarga Dan Kualitas Perikahan Pada Keluarga Nelayan Dan Buruh Tani 'Brondol' Bawang Merah." Jurnal IImu Keluarga Dan Konsumen Vol.12. No.1, 1-12

Putri, G.G., D, P.S, dan Najahi, S. (2013). Perbedaan Self-Acceptance (Penerimaan Diri) Pada Anak Panti Asuhan DItinjau Dari Segi Usia. "Proceeding PESAT (Psikologi, Ekonomi, Sastra, Arsitektur, Dan Teknik Sipil)."

Putri, A.W., Wibhawa, B., dan Gutama, A.S. (2014). Kesehatan Mental Masyarakat Indonesia (Pengetahuan, dan Keterbukaan Masyarakat Terhadap Gangguan Kesehatan Mental. Prosiding KS:Riset dan PKM Vol 2 (2), 147-300

Rahmah, A., A., Rahman, A., A., dan Fitriah, E., A. (2017). Prediktor Kualitas Pernikahan: Penyesuaian Pernikahan dan Nilai Personal. Jurnal Psikologi, Vol 13, No 2, 92-97

Rohma, J . (2018). "Pembentukkan Kepercayaan Diri Anak Melalui Pujian." MARTABAT: Jurnal Perempuan Dan Anak. Vol. 02. No 1, 118-134

Santrock, J. W. (2012). Life - Span Development, Perkembangan Masa Hidup (Edisi Ketigabelas) Jilid I. Jakarta: Erlangga.

Seniawan C. R. (2018). Penerapan Pembelajaran Pada Anak. Jakarta: PT. Indeks.

Setiawani M., dan Stephen T. (2013). Seni Membentuk Karakter Kristen. Surabaya: Momentum.

Setiawati, F., A dan Nurhayati, S., R. (2020). Kualitas Perkawinan Orang Jawa: Tinjauan FAKTOR, Jenis Kelamin, Usia Perkawinan, Jumlah Anak, dan Pengeluaran Keluarga. 
Jurnal IImu Keluarga dan Konsumen, 13(1), 13-24

Simanjuntak, J. (2012). Membangun Kesehatan Mental Keluarga Dan Masa Depan Anak. Jakarta: Gramedia Pustaka Utama.

Sumantri, M. (2014). Modul 1 Pertumbuhan Dan Perkembangan Anak. Jakarta: Universitas Terbuka.

Sommer, M., Ness, O., dan Borg, M. (2018). Helpful Support To Promote Participation In School And Work: Subjective Experiences Of People With Mental Health Problems- A Literature Review. Social Work In Mental Health, 16 (3), 346-366. Doi: 10.1080/15332985.2017.1395778

Sulistiowati, N.M.D, Prapti, N.K.G., Sawitri, N.K.A., Utami, P.A.S., Astuti, I.W., dan Saputra, K. (2015). Pemberdayaan Keluarga Melalui Pemberian Pendidikan Kesehatan Dalam Merawat Anggota Keluarga Dengan Gangguan Jiwa. Jurnal Keperawatan Jiwa. Vol 3 (2), 141-144

Tirtawati, A.A. (2016). Kesehatan Mental Sumber Daya Manusia Para Guru (Implikasi Terhadap Penyelenggaraan Diklat /Pelatihan). Jurnal Kajian Pendidikan Widya Accarya FKIP Universitas Dwijendra, 40-54

Tong. S. (2014). Membesarkan Anak Dalam Tuhan. Surabaya: Momentum.

Tyas, F.P.S., dan Herawati, T. (2017). "Kualitas Pernikahan Dan Kesejahteraan Keluarga Menentukan Kualitas Lingkungan Pengasuhan Anak Pada Pasangan Yang Menikah Usia Muda." Jurnal IImu Keluarga Dan Konsumen Vol 10, No.

Wijayanto, A. (2020). "Peran Orangtua Dalam Mengembangkan Kecerdasan Emosional Anak Usia Dini." Diklus Jurnal Pendidikan Luar Sekolah Vol 1, No.

Willis, S.S. (2013). Konseling Keluarga (Family Counseling): Suatu Upaya Membantu Anggota Keluarga Memecahkan Masalah Komunikasi Di Dalam Sistem Keluarga. Bandung: Alfa Beta

Winurini,S. (2019). Hubungan Religiositas dan Kesehatan Mental Pada Remaja Pesantren di Tabanan. Jurnal Masalah-masalah Sosial, Vol 10, (2).Doi: https://doi.org/10.22212/aspirasi.vl0i2.1428

Wiramihardja. (2015). Pengantar Psikologi Abnormal. Bandung: Refika Adita.

Yuli, C.(2020). "Pola Komunikasi Keluarga Dan Pola Asuh Anak Tkw." Jurnal IImu Komunikasi 2, No. 2 (October 2010). Accessed May 11, 2020. Http://Eprints. Upnjatim.Ac.Id/3186/.

Yusuf, S. (2016). Psikologi Perkembangan Anak dan Remaja. Bandung: RosdaKarya 